\title{
Evaluasi Metode Forecasting Pada Data Kunjungan Wisatawan Mancanegara ke Indonesia
}

\author{
Amin Nur Rais ${ }^{1}$, Rousyati ${ }^{2}$, Indra Jiwana Thira ${ }^{3}$, Desiana Nur Kholifah ${ }^{4}$, Nani Purwati ${ }^{5}$, \\ Yustina Meisella Kristania ${ }^{6}$ \\ ${ }^{1}$ Teknologi Komputer, Universitas Bina Sarana Informatika \\ ${ }^{2}$ Magister Ilmu Komputer, STMIK Nusa Mandiri \\ ${ }^{3}$ Sistem Informasi Kampus Kota Tegal, Universitas Bina Sarana Informatika \\ ${ }^{4}$ Rekayasa Perangkat Lunak, Universitas Bina Sarana Informatika \\ 5 Sistem Informasi Akuntansi, Universitas Bina Sarana Informatika \\ ${ }^{6}$ Sistem Informasi, STMIK Nusa Mandiri
}

Author.E-mail:amin.arv@bsi.ac.id,rousyati.rou@bsi.ac.id,indrathira@gmail.com, desiana.dfh@bsi.ac.id,nani.npi@bsi.ac.id,yustina.yms@nusamandiri.ac.id

\begin{abstract}
Abstrak
Kontrol pembangunan sektor pariwisata untuk mendukung kunjungan wisatawan mancanegara ke destinasi wisata di suatu negara dapat dilakukan dengan cara mengetahui prediksi kunjungan wisatawan mancanegara ke Indonesia, agar pembangunan sektor pariwisata tetap sejalan dengan tren pertumbuhan kunjungan wisatawan mancanegara ke Indonesia. Metode peramalan dalam statistika dapat digunakan dalam memprediksi kunjungan wisatawan mancanegara ke Indonesia. Penelitian ini bertujuan untuk memprediksi kunjungan wisatawan mancanegara ke Indonesia dengan mengimplementasikan metode Simple Moving Average (SMA) dan Single Exponential Smoothing (SES) pada data historis kunjungan wisatawan mancanegara ke indonesia periode tahun 2010 sampai 2017 yang berasal dari Badan Pusat Statistik (BPS). Metode SES menggunakan parameter $\alpha=0.3$ yang memiliki hasil Mean Absolute Percentage Error (MAPE) paling baik diantara hasil pengujian nilai $\alpha$ lainnya. Hasil penelitian menunjukan peramalan menggunakan SMA yang menghasilkan nilai MAPE sebesar $5.96 \%$ lebih unggul dibandingkan dengan metode SES yang menghasilkan nilai MAPE sebesar $6.06 \%$. Berdasarkan kriteria MAPE, baik hasil peramalan menggunakan metode SMA maupun metode SES termasuk pada kriteria MAPE dengan nilai baik sekali.
\end{abstract}

Kata Kunci : Peramalan; Wisatawan, Simple Moving Average; Single Exponential Smoothing;

\begin{abstract}
Control of the development of the tourism sector to support foreign tourist visits to tourist destinations in a country can be done by knowing the predictions of foreign tourist visits to Indonesia, so that the development of the tourism sector remains in line with the growth trend of foreign tourist visits to Indonesia. Forecasting methods in statistics can be used in predicting foreign tourist visits to Indonesia. This study aims to predict foreign tourist visits to Indonesia by implementing the Simple Moving Average (SMA) and Single Exponential Smoothing (SES) methods on historical data on foreign tourist visits to Indonesia from 2010 to 2017 from the Central Statistics Agency (BPS). The SES method uses the parameter $\alpha=0.3$ which has the best Mean Absolute Percentage Error (MAPE) results among other a value tests. The results showed that prediction using SMA which resulted in an MAPE value of 5.96\% was superior to that of the
\end{abstract}


SES method which resulted in an MAPE value of $6.06 \%$. Based on the MAPE criteria, both the forecasting results using the SMA method and the SES method are included in the MAPE criteria with very good scores.

Keywords: Forecasting; Traveler; Simple Moving Average; Single Exponential Smoothing;

\section{Pendahuluan}

Indonesia merupakan salah satu negara yang memiliki destinasi wisata internasional yang dapat menarik minat wisatawan mancanegara untuk mengunjunginya. Pada periode tahun 19942002 kunjungan wisatawan mancanegara ke Indonesia secara rata- rata meningkat sebesar 3,0 persen; dan pada periode tahun 2004-2012 sebesar 13,7 persen (Oka \& Kencana, 2016). Berdasarkan data UNWTO pertumbuhan kunjungan wisatawan mancanegara ke Indonesia tahun 2017 tercatat sebesar 14,04 juta kunjungan atau naik $16,77 \%$ dibandingkan tahun sebelumnya. Hal ini menunjukan bahwa pembangunan sektor pariwisata harus terus dilakukan oleh Pemerintah Indonesia untuk memfasilitasi wisatawan mancanegara yang berkunjung ke Indonesia. Pembangunan sektor wisata tentunya harus berdasarkan keputusan-keputusan strategis yang salah satunya berasal dari data hitoris kunjungan wisatawan mancanegara dan prediksi kunjungan di masa yang akan datang. Perbandingan Double Moving Average dan Double Exponential Smoothing untuk Peramalan Jumlah Kedatangan Wisatawan
Mancanegara di Bandara Ngurah Rai. Double Exponential Smoothing memiliki akurasi lebih baik dibandingkan Double Moving Average pada peramalan jumlah kedatangan wisatawan mancanegara di Bandara Ngurah Rai (Hudiyanti et al., 2019). Pendekatan Fuzzy Pada Peramalan Jumlah Kunjungan Wisatawan Mancanegara ke Kabupaten Badung. penelitian menunjukkan akurasi peramalan insample untuk model fuzzy kami sebesar 2,48 persen (Oka \& Kencana, 2016). Sistem Informasi Prediksi Jumlah Wisatawan Pada Jawa Timur Park Group Kota Wisata Batu Menggunakan Metode Forecasting, menghasilkan sistem yang dapat memberikan kemudahan pada bagian Marketing Jawa Timur Park Group dalam membuat kebijakan renca kedatangan jumlah wisatawan diperiode berikutnya (Saputra \& Ekojono, 2016). Peramalan Jumlah Wisatawan Australia Yang Berkunjung Ke Bali Menggunakan Multivariat Fuzzy Time Series, menunjukkan bahwa wisatawan Australia pada bulan Juli 2014 akan mengunjungi Bali sebanyak 91.056 wisatawan, bersama tingkat kesalahan rata-rata $6,87 \%$ (Satria, 
Sukarsa, \& Jayanegara, 2015).Beberapa peneliti sebelumnya melakukan peramalan dengan berbagai metode tetapi masih terfokus pada daerah atau destinasi tertentu saja. Sementara itu (Molydah, 2018) telah melakukan peramalan terhadap kunjungan wisatawan mancanegara ke Indonesia menggunakan metode SARIMA dan Support Vector Machine (SVM) tetapi dengan membagi data historis berdasarkan pintu masuk wisatawan mancanegara ke Indoensia. Maka disana terdapat keterbatasan studi tentang peramalan kunjungan wisatawan mancanegara ke Indonesia dengan luang lingkup yang lebih luas yang hanya meneliti di salah satu destinasi wisata. Oleh karena itu, dalam penelitian ini intens untuk membahas peramalan kunjungan wisatawan mancanegara ke Indonesia akan dilakukan menggunakan metode Simple Moving Average (SMA) dan Metode Single Exponetial Smoothing (SES). Tujuan dari penelitian ini adalah memprediksi kunjungan wisatawan mancanegara ke Indonesia dengan mengimplementasikan metode Simple Moving Average (SMA) dan Single Exponential Smoothing (SES) pada data historis kunjungan wisatawan mancanegara ke indonesia periode tahun 2010 sampai 2017 yang berasal dari Badan Pusat Statistik (BPS).

\section{Metode Penelitian}

Pada penelitian terdahulu, metode SMA digunakan untuk meramal kebutuhan stok ATK pada suatu kantor untuk mengendalikan stok setiap bulannya (Putra \& Imam Solikin, 2019). Selain untuk meramalkan kebutuhan ATK, metode SMA juga digunakan untuk meramal penjualan sehingga dapat meramalkan kebutuhan pasar nantinya (Prasetya, 2017). Dengan menggunakan SMA, kebutuhan data dalam rentang waktu tertentu diperlukan karena berhubungan dengan hasil ramalan yang dihasilkan (Landia, 2020). Sehingga, proses ramalan yang dilakukan secara manual dengan nilai akurasi yang kurang dapat diatasi dengan penerapan metode SMA dengan sumber data rentang waktu tertentu (Utari \& Silalahi, 2016).

Pada prediksi penjualan produk pada bulan berikutnya, metode SES dapat digunakan (Alfarisi, 2017). Perencanaan kedepan perlu dilakukan agar dapat memprediksi masa depan misalnya dalam persiapan finansial sebuah perusahaan dengan menggunakan metode SES (Suriansyah et al., 2020). Dengan menggunakan metode SES dirasa tepat digunakan untuk meramal data yang berupa time series sehingga dapat mengefisiensikan pengeluaran (Primayoga, 2016).

Pada perbandingan penggunaan metode SMA dan WMA pada peramalan 
aksptor $\mathrm{KB}$, metode peramalan dengan SMA selama 3 bulan menjadi metode yang lebih tepat (Raharjo et al., 2016). Pada penelitian yang dilakukan oleh Waskita dengan membandingkan metode SMA, DES, dan LS didapatkan hasil metode SMA memiliki nilai paling akurat (SARI, 2013). Anggi dkk melakukan penelitian dengan membandingkan metode SES dan ESA untuk melakukan ramalan pada data penjualan, dimana hasil yang dicapai menunjukkan metode SES lebih tepat digunakan untuk meramal history penjualan (Hartono et al., 2012).

Dalam penelitian ini, untuk melakukan ramalan pada data kunjungan wisatawan mancanegara ke Indonesia dilakukan dengan membandingkan metode SMA dan SES. Proses pembandingan metode SMA dan SES dilakukan dengan melihat nilai MAPE yang dihasilkan, sehingga mendapatkan hipotesis :

H1 : Metode SMA lebih baik dalam melakukan peramalan daripada metode SES

Untuk melakukan penelitian dengan hipotesis H1, peneliti melakukan tahapantahapan sebagai mana tercantum pada Gambar 1.

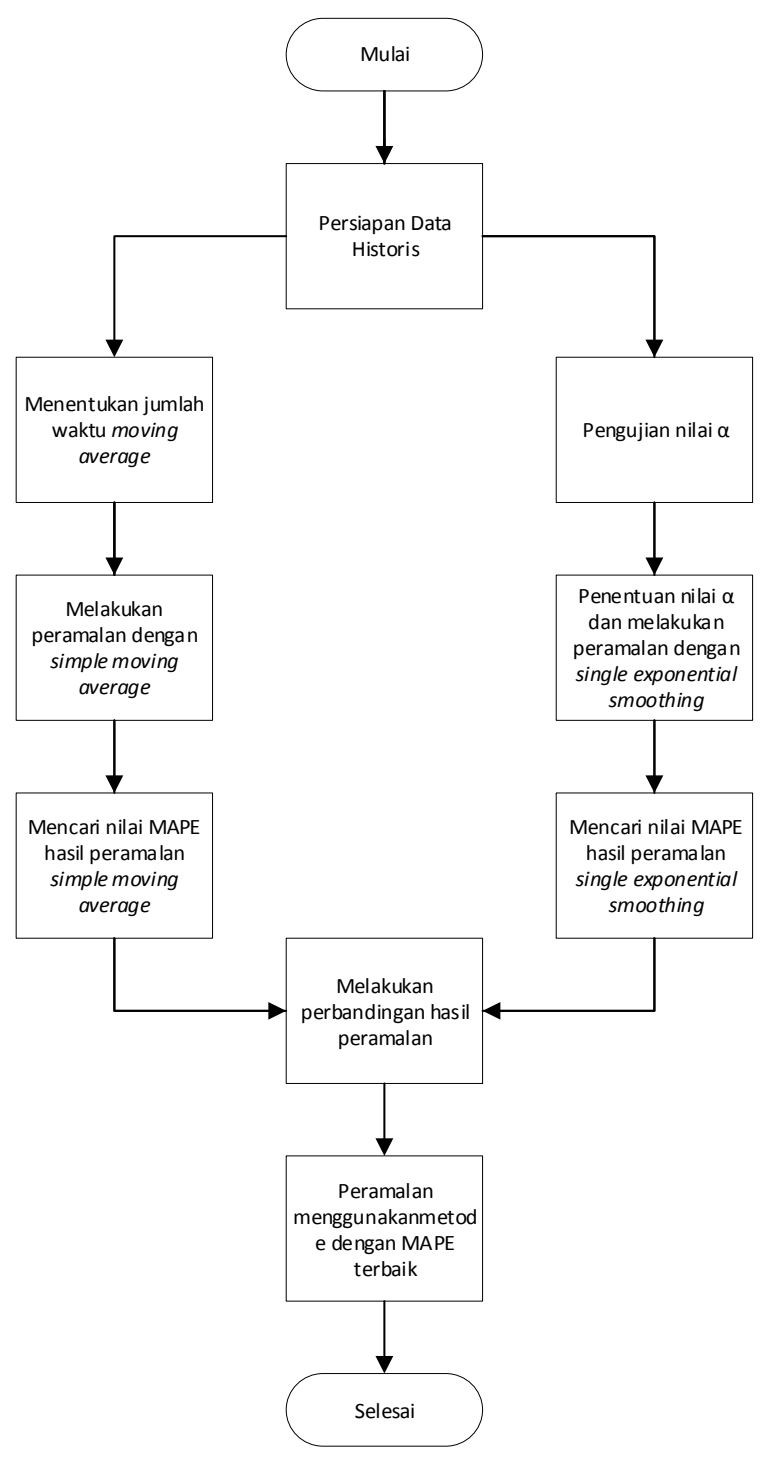

Gambar 1. Alur Penelitian

Pertama adalah menyiapkan data historis, selanjutnya melakukan peramalan terhadap data historis menggunakan metode SMA dan SES, kemudian menghitung akurasi dari hasil peramalannya menggunakan Mean absolute percentage error (MAPE).

\subsection{Simple Moving Average}

Metode simple moving average (SMA) akan menggunakan rumus sebagai berikut: 


$$
M A P E=\frac{1}{n} \sum_{i=1}^{n}\left|P E_{t}\right|
$$

$$
S_{t+1}=\frac{X_{t}+X_{t-1}+\cdots X_{t-n+1}}{n}
$$

$S_{t+1}=$ forecast untuk periode ke $\mathrm{t}+1$

$X_{t} \quad=$ data periode ke $\mathrm{t}$

$n \quad=$ jangka waktu moving average

$$
P E_{t}=\left(\left|\frac{Y_{t}-F_{t}}{Y_{t}}\right|\right) X 100
$$

Pada penelitian ini ditentukan nilai $n$ adalah 3, yang berarti penelitian akan menggunakan SMA dengan pergerakan tiga bulanan.

\subsection{Single Exponential Smoothing}

Metode single exponential smoothing (SES) akan menggunakan rumus sebagai berikut:

$$
F_{t}=\alpha X_{t}+(1-\alpha) F_{t-1}
$$

$$
\begin{array}{ll}
F_{t} & =\text { Peramalan untuk periode } t \\
X_{t} & =\text { Nilai Aktual untuk periode } t-1 \\
\alpha & =\text { parameter exponential }(0-1) \\
F_{t-1} & =\text { peramalan pada periode } t-1
\end{array}
$$

Dimana PE (percentage of error) adalah

$n$ adalah jumlah data yang di observasi, $Y_{t}$ adalah nilai actual dan $F_{t}$ adalah nilai hasil peramalan pada periode $t$. MAPE dibagi kedalam empat kriteria (Setiawan et al., 2017). Kriteria MAPE dapat dilihat pada Tabel 1.

Tabel 1. Kriteria MAPE

\begin{tabular}{ccc}
\hline No & Nilai MAPE & Deskripsi \\
\hline 1 & $<10 \%$ & Baik Sekali \\
\hline 2 & $10 \%-20 \%$ & Baik \\
\hline 3 & $20-50 \%$ & Cukup \\
\hline 4 & $>50 \%$ & Buruk
\end{tabular}

Sumber: (Setiawan et al., 2017)

Nilai $\alpha$ akan ditentukan dengan cara melakukan pengujian terhadap nilai $\alpha$ dari 0,1 sampai dengan 0,9 dan $\alpha$ yang akan digunakan adalah $\alpha$ yang mendapatkan nilai akurasi peramalan terbaik pada saat pengujian.

\subsection{Mean Absolute Percentage Error (MAPE)}

MAPE digunakan untuk mengukur akurasi dari peramalan (Elmunim et al., 2013) baik untuk SMA maupun SES akurasinya akan diukur menggunakan MAPE dengan rumus sebagai berikut :

\section{Pembahasan}

Data historis yang digunakan adalah data historis kunjungan wisatawan mancanegara ke Indonesia periode Januari tahun 2010 sampai dengan Desember 2017 yang berasal dari Badan Pusat Statistik (BPS). Data historis dapat dilihat pada Tabel 2.

Tabel 2. Data Kunjungan Wisatawan Mancanegara Ke Indonesia

\begin{tabular}{ccc}
\hline Tahun & Bulan & Jumlah \\
\hline 2010 & Januari & 493,799 \\
\hline 2010 & Februari & 523,135
\end{tabular}




\begin{tabular}{ccc}
2010 & Maret & 594,242 \\
\hline 2010 & April & 555,915 \\
\hline 2010 & Mei & 600,031 \\
\hline 2010 & Juni & 613,422 \\
\hline$\ldots$ & $\ldots$ & $\ldots$ \\
\hline 2017 & Juli & $1,370,591$ \\
\hline 2017 & Agustus & $1,393,243$ \\
\hline 2017 & September & $1,250,231$ \\
\hline 2017 & Oktober & $1,161,565$ \\
\hline 2017 & November & $1,062,030$ \\
\hline 2017 & Desember & $1,147,031$
\end{tabular}

Sumber: Badan Pusat Statistik (BPS)

Pada Tabel 2 dapat dilihat bahwa jumlah kunjungan wisatawan mancanegara ke pada bulan Januari 2010 hingga Bulan Agustus 2017 mengalami peningkatan dan penurunan.

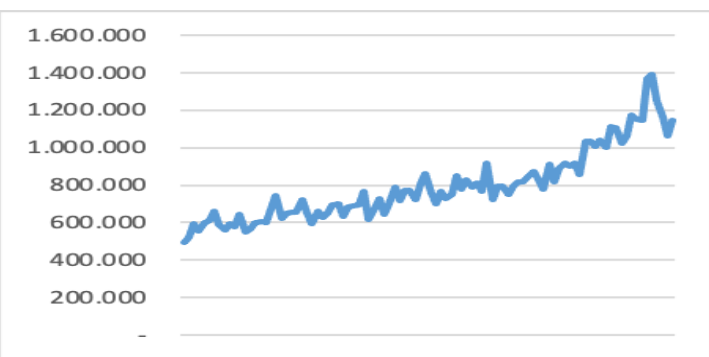

Gambar 1. Grafik Kunjungan Wisata Mancanegara

Pada Gambar 1 dapat dilihat bahwa grafik kunjungan wisatawan mancanegara mengalami dari tahun 2010 hingga 2017 tidak menentu. Namu secara global data jumlah kunjungan meningkat dari Januari 2010 sejumlah 493.799 hingga pada bulan Desember 2017 menjadi 1,147,031.

\subsection{Simple Moving Average}

Untuk mendapatkan nilai peramalan dari data historis menggunakan metode SMA, data historis pada Table 2 diolah menggunakan rumus (1). Karena nilai $n$ yaitu jangka waktu moving average sudah ditentukan dengan nilai 3, maka data yang bisa diprediksi adalah mulai dari bulan keempat pada data historis yaitu April 2010.

Peramalan untuk April 2010 didapatkan dengan penjumlahan data aktual pada bulan Maret, Februari dan Januari 2010 dibagi nilai moving average yaitu 3 .

$$
\begin{aligned}
& S_{t+1}=\frac{X_{t}+X_{t-1}+\cdots X_{t-n+1}}{n} \\
& S_{t+1}=\frac{594,242+523,135+493,799}{3} \\
& S_{t+1}=537,059
\end{aligned}
$$

Peramalan untuk bulan selanjutnya dilakukan dengan rumus yang sama hanya saja data aktual yang digunakan berbeda. Peramalan akan menggunakan data aktual tiga bulan terakhir sebelum bulan yang akan di prediksi. Berikut perhitungan peramalan untuk Mei 2010 yaitu menggunakan data aktual dari bulan April, Maret dan Februari 2010:

$$
\begin{aligned}
& S_{t+1}=\frac{555,915+594,242+523,135}{3} \\
& S_{t+1}=600,031
\end{aligned}
$$

Dengan melakukan aturan yang sama pada seluruh data historis, maka dihasilkan data hasil peramalan menggunakan metode SMA pada Tabel 3. 
Tabel 3. Hasil Peramalan Menggunakan Simple Moving Average

\begin{tabular}{cccc}
\hline Tahun & Bulan & Jumlah & Forecast \\
\hline 2010 & Januari & 493,799 & - \\
\hline 2010 & Februari & 523,135 & - \\
\hline 2010 & Maret & 594,242 & \multicolumn{1}{c}{-} \\
\hline 2010 & April & 555,915 & \multicolumn{1}{c}{537,059} \\
\hline 2010 & Mei & 600,031 & \multicolumn{1}{c}{557,764} \\
\hline 2010 & Juni & 613,422 & \multicolumn{1}{c}{583,396} \\
\hline$\ldots$ & $\ldots$ & $\ldots$ & $\ldots$ \\
\hline 2017 & Juli & $1,370,591$ & $1,154,658$ \\
\hline 2017 & Agustus & $1,393,243$ & $1,221,060$ \\
\hline 2017 & September & $1,250,231$ & $1,302,612$ \\
\hline 2017 & Oktober & $1,161,565$ & $1,338,022$ \\
\hline 2017 & November & $1,062,030$ & $1,268,346$ \\
\hline 2017 & Desember & $1,147,031$ & $1,157,942$ \\
\hline & Pada Tabel $3 \quad$ didapat & hasil
\end{tabular}

peramalan menggunakan metode Simple Moving Average. Hasil peramalan secara keseluruhan rata-rata mendekati dengan data aktual namun ada jumlah lebih besar dan ada juga yang lebih kecil dari data aktual jumlah kunjungan wisatawan mancanegara.

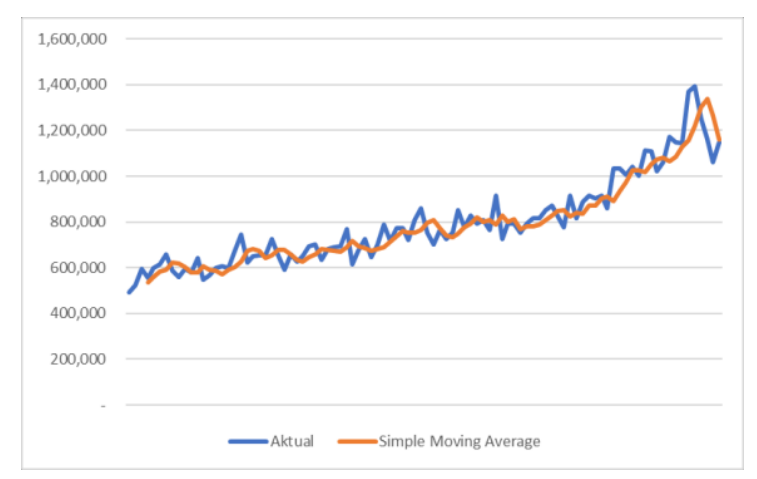

Gambar 2. Perbandingan Data Aktual Hasil Peramalan dengan SMA
Berdasarkan Gambar 2. Hasil peramalan data dengan SMA tidak jauh signifikan dibandingkan dengan data aktual.

Masing-masing data hasil peramalan menggunakan metode SMA dihitung akurasinya menggunakan rumus (4).

$$
P E_{t}=\left(\left|\frac{Y_{t}-F_{t}}{Y_{t}}\right|\right) X 100
$$

$Y_{t}$ adalah nilai aktual dan $F_{t}$ adalah nilai hasil peramalan pada periode $t$. Untuk hasil peramal bulan April 2010, $Y_{t}=555915$ dan $F_{t}=537059$ maka,

$P E_{t}=\left(\left|\frac{555915-537059}{555915}\right|\right) \times 100$

$P E_{t}=3.35 \%$

Untuk dapat menghasilkan MAPE, semua data hasil peramalan dihitung akurasinya. MAPE dihasilkan dari perhitungan rumus (3) yang merupakan perhitungan rata-rata akurasi dari keseluruhan data. Hasil perhitungan didapatkan MAPE untuk hasil peramalan menggunakan metode SMA sebesar 5.96\% dengan kesalahan tertinggi sebesar 19.43\% pada November 2017 dan kesalahan terendah sebesar $0.06 \%$ pada Juli 2014 .

\subsection{Single Exponential Smoothing}

Tahap pertama yang dilakukan pada metode SES adalah melakukan pengujian nilai $\alpha$ untuk mencari nilai $\alpha$ yang memiliki MAPE paling baik. Nilai $\alpha$ yang diuji adalah $\alpha$ dengan nilai $0.1,0.2,0.3,0.4,0.5$, 
0.6, 0.7, 0.8, 0.9 dengan data uji adalah periode November 2012 sampai dengan Desember Tahun 2013. Hasil uji nilai $\alpha$ dapat dilihat pada Gambar 3.

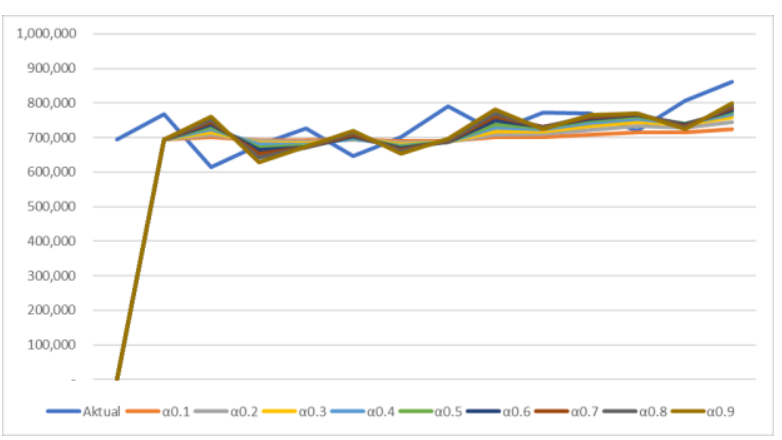

Gambar 3. Grafik Pengujian Parameter $\alpha$

Berdasarkan hasil pengujian didapatkan nilai $\alpha$ yang memiliki MAPE paling baik adalah $\alpha=0.3$ dengan MAPE 6.89\%. maka $\alpha=0.3$ akan digunakan sebagai parameter exponential pada peramalan seluruh data historis menggunakan metode SES. Daftar MAPE hasil pengujian nilai $\alpha$ terdapat pada Tabel 4.

Tabel 4. Daftar MAPE Parameter $\alpha$

\begin{tabular}{cr}
\hline A & MAPE \\
\hline 0.1 & $7.46 \%$ \\
\hline 0.2 & $7.08 \%$ \\
\hline 0.3 & $6.89 \%$ \\
\hline 0.4 & $6.98 \%$ \\
\hline 0.5 & $7.27 \%$ \\
\hline 0.6 & $7.65 \%$ \\
\hline 0.7 & $8.08 \%$ \\
\hline 0.8 & $8.54 \%$ \\
\hline 0.9 & $8.99 \%$
\end{tabular}

Setelah mendapatkan nilai $\alpha=0.3$, peramalan data kunjungan wisatawan mancanegara ke Indonesia dengan menggunakan metode SES dapat dilakukan dengan menggunakan rumus (2). Bulan Maret 2010 adalah bulan pertama yang bisa dilakukan permalan dengan cara sebagai berikut:

$$
F_{t}=\alpha X_{t}+(1-\alpha) F_{t-1}
$$

$$
\begin{array}{ll}
F_{t} & =\text { Peramalan untuk periode } t \\
X_{t} & =\text { Nilai Aktual untuk periode } t-1 \\
\alpha & =\text { parameter exponential }(0-1) \\
F_{t-1} & =\text { peramalan pada periode } t-1
\end{array}
$$

$F_{t}$ adalah peramalan untuk periode Maret $2010, X_{t}$ adalah nilai aktual untuk periode Februari 2010, $\alpha$ menggunakan nilai 0,3 dan $F_{t-1}$ adalah nilai peramalan pada periode Februari 2010. Karena nilai peramalan Februari 2010 belum ada maka nilai aktual januari 2010 menjadi nilai peramalan Februari 2010 atau $F_{t-1}$.

$$
\begin{gathered}
F_{\text {maret }}=\alpha X_{\text {februari }}+(1-\alpha) F_{\text {februari }} \\
F_{\text {maret }}=0,3 * 523135+(1-0,3) * 493733 \\
F_{\text {maret }}=502600
\end{gathered}
$$

Peramalan periode berikutnya adalah April 2010, $X_{t}$ adalah nilai aktual untuk periode Maret 2010, $\alpha$ menggunakan nilai 0,3 dan $F_{t-1}$ adalah nilai peramalan pada periode Februari 2010. 


$$
\begin{gathered}
F_{\text {april }}=\alpha X_{\text {maret }}+(1-\alpha) F_{\text {maret }} \\
F_{\text {april }}=0,3 * 594242+(1-0,3) * 502600 \\
F_{\text {april }}=530092
\end{gathered}
$$

Cara yang sama dilakukan pada seluruh data historis untuk mendapatkan hasil peramalan untuk setiap bulannya. Hasil peramalan menggunakan metode SES dapat dilihat pada Tabel 5.

Tabel 5. Hasil Peramalan Menggunakan Single Exponential Smoothing

\begin{tabular}{cccc}
\hline Tahun & Bulan & Jumlah & Ramalan \\
\hline 2010 & Januari & 493,799 & - \\
\hline 2010 & Februari & 523,135 & - \\
\hline 2010 & Maret & 594,242 & 502,600 \\
\hline 2010 & April & 555,915 & 530,092 \\
\hline 2010 & Mei & 600,031 & 537,839 \\
\hline 2010 & Juni & 613,422 & 556,497 \\
\hline$\ldots$ & $\ldots$ & $\ldots$ & $\ldots$ \\
\hline 2017 & Juli & $1,370,591$ & $1,116,530$ \\
\hline 2017 & Agustus & $1,393,243$ & $1,192,748$ \\
\hline 2017 & September & $1,250,231$ & $1,252,896$ \\
\hline 2017 & Oktober & $1,161,565$ & $1,252,097$ \\
\hline 2017 & November & $1,062,030$ & $1,224,937$ \\
\hline 2017 & Desember & $1,147,031$ & $1,176,065$ \\
\hline & & & \\
\hline
\end{tabular}

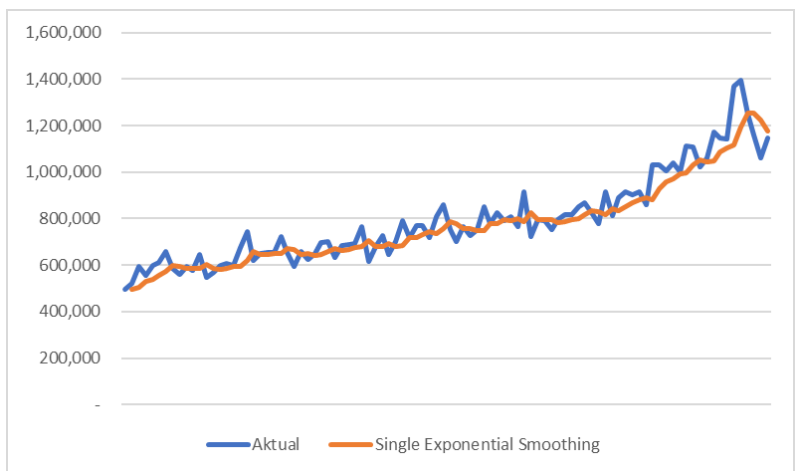

Gambar 4. Grafik perbandingan data aktual dan hasil peramalan SES

Gambar 4. Hasil peramalan data dengan metode SES lebih banyak jumlah kunjungan yang meningkat atau lebih besar dibandingkan data aktual.

Untuk menghitung akurasi dari hasil peramalan metode SES menggunakan rumus (3) untuk menghitung MAPE dan rumus (4) untuk menghitung akurasi masing-masing data peramalan. Gambar 5 menunjukan perbandingan antara data aktual, hasil peramalan metode SMA dan hasil peramalan metode SES.

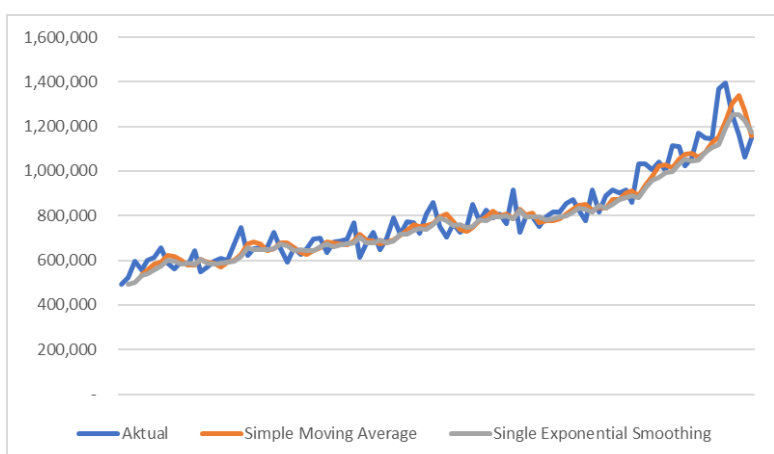

Gambar 5. Grafik perbandingan data aktual, hasil peramalan SMA dan SES

Pada penelitian ini Gambar 5. perhitungan menunjukan bahwa permalan menggunakan metode SES mempunyani 
nilai MAPE sebesar $6.06 \%$ dengan kesalahan paling rendah sebesar $0.01 \%$ pada bulan Februari 2013 dan kesalahan tertinggi sebesar 18.54\% pada bulan Juli 2017.

Metode Single Exponential Smoothing dapat mengatasi kelemahan Simple Moving Average yang pembobotannya sama rata setiap tahunnya, sehingga penggunaan Single Exponential Smoothing berhasil menutupi kekurangan metode Simple Moving Average (Landia, 2020). Namun, pada hasil penelitian ini SMA yang menghasilkan nilai MAPE sebesar 5.96\% lebih unggul dibandingkan dengan metode SES yang menghasilkan nilai MAPE sebesar $6.06 \%$. Hal tersebut terjadi karena hasil prediksi jumlah kunjungan wisatawan menggunakan SMA hasilnya lebih mendekati data aktual dibandingkan dengan SES. Sehingga hipotesis dapat diterima dengan melihat hasil prediksi jumlah kunjungan wisatawan SMA yang lebih mendekati aktual.

\section{Penutup}

Dalam penelitian ini membandingkan penggunaan metode SMA dan SES untuk meramal data kunjungan wisatawan mancanegara ke Indonesia. Penelitian ini telah menemukan bahwa penggunaan metode SMA menghasilkan nilai MAPE lebih unggul dengan nilai $5.96 \%$ dari metode SES yang menghasilkan nilai
MAPE $6.06 \%$. sedangkan evaluasi yang dapat dilakukan pada penelitian yang akan datang dapat dilakukan dengan membandingkan metode yang sejenis dan optimasi untuk medapatkan hasil yang lebih aktual.

\section{References}

[1] Alfarisi, S. (2017). Sistem Prediksi Penjualan Gamis Toko QITAZ Menggunakan Metode Single Exponential Smoothing. JABE (Journal Of Applied Business And Economic), 4(1),

Https://Doi.Org/10.30998/Jabe.V4i1.19 08

[2] Elmunim, N. A., Abdullah, M., Hasbi, A. M., \& Bahari, S. A. (2013). ShortTerm Forecasting Ionospheric Delay Over UKM, Malaysia, Using The HoltWinter Method. July, 1-3.

[3] Hartono, A., Dwijana, D., \& Handiwidjojo, W. (2012). Perbandingan Metode Single Exponential Smoothing Dan Metode Exponential Smoothing Adjusted For Trend (Holt's Method) Untuk Meramalkan Penjualan. Studi Kasus: Toko Onderdil Mobil "Prodi, Purwodadi." Jurnal EKSIS, 5(1), 8-18.

[4] Hudiyanti, C. V., Bachtiar, F. A., \& Setiawan, B. D. (2019). Perbandingan Double Moving Average Dan Double Exponential Smoothing Untuk 
Peramalan Jumlah Kedatangan

Wisatawan Mancanegara Di Bandara

Ngurah Rai. Jurnal Pengembangan

Teknologi Informasi Dan Ilmu

Komputer, 3(3), 2667-2672.

[5] Landia, B. (2020). PERAMALAN

JUMLAH MAHASISWA BARU

DENGAN

EXPONENTIAL

SMOOTHING DAN MOVING

AVERAGE Barkah. Journal of

Chemical Information And Modeling, 53(9), 1689-1699.

[6] Molydah, S. (2018). ANALISIS

PERBANDINGAN IMPLEMENTASI

SARIMA DAN SUPPORT VECTOR

MACHINE (SVM) DALAM PREDIKSI

$J U M L A H$

WISATAWAN

MANCANEGARA.

[7] Oka, T. B., \& Kencana, E. N. (2016).

Pendekatan Fuzzy Pada Peramalan Jumlah Kunjungan Wisatawan Mancanegara Ke Kabupaten Badung. Jurnal Matematika, 6(Desember). Https://Doi.Org/10.24843/JMAT.2016.

V06.I02.P76

[8] Prasetya, B. P. (2017). Penerapan Metode Single Moving Average (SMA) Pada Aplikasi Peramalan Penjualan Di Kedai Digital \#24 Kediri. Artikel Skripsi, 1-6.

[9] Primayoga, P. (2016). RANCANG BANGUN SISTEM PREDIKSI PERSEDIAAN BAHAN BAKU
PRODUKSI

$B A G L O G$

MENGGUNAKAN METODE SINGLE EXPONTIAL SMOOTHING (SES) (STUDI KASUS UD. MITRA ALAM SEJAHTERA BONDOWOSO).

[10] Putra, M. S., \& Imam Solikin. (2019). Aplikasi Peramalan Stok Alat Tulis Kantor (Atk) Menggunakan Metode Single Moving Average (Sma)Pada Pt. Sinar Kencana Multi Lestari. CESS (Journal Of Computer Engineering System And Science), 4(No 2), 236-241.

[11] Raharjo, E. S., Hayati, M. N., \& Wahyuningsih, S. (2016). Pemantauan Peramalan Akseptor KB Baru Provinsi Kalimantan Timur Menggunakan Simple Moving Average Dan Weighted Moving Average Dengan Metode Tracking Signal Monitoring Forecasting New Acceptors KB East Kalimantan Province Using Simple Moving Average And We. Jurnal EKSPONENSIAL, 7, 17-22.

[12] Saputra, Y. L., \& Ekojono. (2016). Sistem Informasi Prediksi Jumlah Wisatawan Pada Jawa Timur Park Group Kota Wisata Batu Menggunakan Metode Forecasting. Jurnal Informatika Polinema, 2(3).

[13] SARI, W. (2013). PERBANDINGAN METODE DOUBLE EXPONENTIAL 
SMOOTHING, SIMPLE MOVING

AVERAGE DAN LEAST SQUARE

UNTUK FORECASTING

PENJUALAN SEMEN. Journal Of

Chemical Information And Modeling, 53(9), 1689-1699.

[14] SATRIA, I. M. C., SUKARSA, I. K. G., \& JAYANEGARA, K. (2015).

Peramalan Jumlah Wisatawan Australia Yang Berkunjung Ke Bali Menggunakan Multivariat Fuzzy Time Series. E-Jurnal Matematika, 4(3), 90. Https://Doi.Org/10.24843/MTK.2015.V 04.I03.P094

[15] Setiawan, W., Juniati, E., \& Farida, I. (2017). The Use Of Triple Exponential Smoothing Method (Winter) In Forecasting Passenger Of PT Kereta Api Indonesia With Optimization Alpha, Beta, And Gamma Parameters. Proceeding - 2016 2nd International Conference On Science In
Information Technology, Icsitech 2016: Information Science For Green Society And Environment, 198-202. Https://Doi.Org/10.1109/Icsitech.2016.7 852633

[16] Suriansyah, M., Nugroho, B., \& Puspaningrum, E. Y. (2020). SISTEM PREDIKSI KENAIKAN VOLUME PENUMPANG , PESAWAT , DAN BAGASI MENGGUNAKAN METODE. Jurnal Informatika Dan Sistem Informasi (Jifosi), 1(3), 845-850. [17] Utari, H., \& Silalahi, N. (2016). Perancangan Aplikasi Peramalan Permintaan Kebutuhan Tenaga Kerja Pada Perusahaan Outsourcing Menggunakan Algoritma Simple Moving Average. Jurnal TIMES, 5(2), 1-5. Http://Ejournal.StmikTime.Ac.Id/Index.Php/Jurnaltimes/Artic le/View/546 